\title{
REVIEW
}

\section{THE USE OF NURSING DIAGNOSES IN CLINICAL PRACTICE}

\author{
Eva Mynaříková ${ }^{1}$, Katarína Žiaková ${ }^{2}$ \\ ${ }^{1}$ Division of Nursing Care, University Hospital Ostrava, Czech Republic \\ ${ }^{2}$ Department of Nursing, Jessenius Medical Faculty in Martin, Comenius University in Bratislava, Slovakia
}

Received March 25, 2014

Accepted July 27, 2014

\begin{abstract}
Aim: The aim was to determine the error rate and frequency of nursing diagnoses used in clinical practice by the means of analysis of available literature, and to reveal the factors influencing the accuracy and occurrence of nursing diagnoses. Methods: The following databases (1993-2013) were used as the data source for the performed analysis: PubMed, ProQuest and Google Scholar. A total of thirty-nine data sources were utilized for data processing: predictive correlational studies (9), retrospective studies using patient data (7), cross-sectional studies (4), systematic reviews (3), cohort studies (3), a randomized trial (1), and a longitudinal analysis (1). The data were also obtained from educational texts (7), review articles (2) and expert disputations (2). Results: Identical problems in formulation as well as accuracy of the nursing concepts have been repeatedly observed during the monitoring of occurrence of the error rate in nursing diagnoses. Noted imperfections concerned identification of determining characters, and especially related factors. Diagnoses regarding dysfunctional physical needs prevailed, whereas diagnoses in the psychosocial and spiritual areas were absent. The analysis of literature data showed that the factors influencing the accuracy and occurrence of nursing diagnoses in practice include the nurses and their education and experience in nursing diagnostics, the way the nursing care is organized, technologies of the nursing documentation and institutional support, especially in the form of adequate staffing. Conclusion: In order to be able to provide beneficent, effective and safe care, it is necessary for managers of individual healthcare establishments to target the strategy on the system as a whole, that is, on mutual interconnection of individual components: the people, environment, process and technologies.
\end{abstract}

Key words: nursing diagnosis, accuracy, frequency, education, influencing factors, clinical practice.

\section{Introduction}

Standardized terms and definitions are required in order to ensure effective and high-quality nursing practice. Standard nursing terminology enables to formulate nursing problems, interventions, and to assess the outcomes of nursing care. Furthermore, nursing terminology facilitates communication among nursing professionals and other healthcare providers. Nursing terminology is one of the basic attributes of establishing nursing as a scientific discipline. Nursing is being developed via interconnection, as well as tension among three constitutive elements: theory, research and nursing practice. A part of the nursing language is being formulated and consequently used in every one of these three areas. Thus the whole community participates upon the formulation of the language, its

Corresponding author: Eva Mynařiková, Division of Nursing Care, University Hospital Ostrava, 17. listopadu 1790, Ostrava, Czech Republic, email: eva.mynarikova@fno.cz. subsequent codification and use of individual terms, resulting in specific expert terminology. The use of unambiguous and well-established terminology constitutes the basis of classification systems in nursing care. Established terminology helps nurses make correct decisions, and at the same time enables them to perform research activities in clinical settings, with the use of the extensive database of terms, which is being created due to the applied terminology. The importance of established nursing terminology might be summarized in the following points:

- Support of professional responsibility and individuality through definition of independent activities in nursing practice.

- Possibility of testing the validity of nursing diagnoses, outcomes and interventions used in order to achieve them. 
- More effective and feasible financial planning of performance of nursing activities.

- Improving the efficacy of mutual communication between nurses and other healthcare professionals.

- Use in teaching, with the impact upon familiarization with expert terminology (Žiaková, Holmanová, Čáp, 2008, p. 83-86).

In order to precisely identify the patient problems, that is, nursing diagnoses, it is possible to use the NANDA International diagnostic system. This system introduces standardized names of nursing diagnoses, together with numerical codes and definitions; at the same time, the system offers an overview of characteristic features, related or risk factors of the diagnoses, based upon which it is possible to confirm the occurrence of an individual nursing diagnosis in a patient, and thus make a diagnostic conclusion. A precise and documentable nursing diagnostic conclusion constitutes the basis for decisions regarding suitable nursing interventions, which are performed in the patient by a team of nursing professionals, in cooperation with a team of other healthcare professionals (Marečková et al., 2013, p. 7).

Even though nursing diagnoses do not present a novelty in the Czech nursing care, as their use experienced the largest boom in the second half of the 1990s, it is still not possible to speak about a systematic use of them. As of today, the use of nursing diagnostics in healthcare establishments in the course of the nursing process may be considered commonplace. The Decree No. 98/2012 Coll. concerning nursing documentation determines that the nursing record must also contain a description of the nursing problem in the patient, or a nursing diagnosis (Czech, 2012). The use of nursing diagnostics in healthcare establishments is also monitored by national, as well as international accreditation bodies (e.g. Joint Accreditation Commission, Joint Commission International). Nevertheless, there exists no legally binding regulation in the Czech Republic, which would determine which classification system should be used in practice. The view upon applying the nursing diagnostics in clinical practice varies, and every healthcare establishment uses its own diagnostic summaries.

\section{Aim}

The aim of the review study was to determine the most frequently occurring mistakes in the nursing diagnostics, and the frequency of nursing diagnoses used in clinical practice, together with factors influencing the accuracy and occurrence of nursing diagnoses in clinical practice.

\section{Methods}

\section{Eligibility criteria}

The criteria for selection of sources included the source language (Czech, Slovak and English). Various publications dealing with nursing diagnostics and its use in clinical practice were selected. Inclusion criteria: the accuracy of nursing diagnoses (formulation, diagnostic elements), documentation of nursing diagnoses, frequency of nursing diagnoses, factors influencing the use and accuracy of nursing diagnoses. Exclusion criteria: validation studies of individual nursing diagnoses, case reports.

\section{Sources}

The following databases were searched (1993-2013): PubMed, ProQuest and Google Scholar. The data was also searched for in the following publications: International Journal of Nursing Terminologies and Classifications (8), Journal of Clinical Nursing (3), Journal of Advanced Nursing (2), Applied Nursing Research, The Journal of Continuing Education in Nursing, International Journal of Nursing Practice, Journal of the American Medical Directors Association, Journal of Nursing Education, Nursing Outlook, The Online Journal of Issues in Nursing, The Permanente Journal, Medical Care and International Journal of Medical Informatics. As far as Czech periodicals are concerned, the following journals were analyzed: Kontakt (2) and Ošetrovatelství a porodní asistence (2). On four instances, presentations from conference abstracts were also used, and in eight cases, the information was obtained from other types of expert publications.

\section{Search}

The search was performed using the key words nursing diagnosis, accuracy, frequency, nursing documentation, nurses, clinical practice, education, influencing factors and environmental elements, in combination with the Boolean operators AND/OR.

\section{Study selection}

Predictive correlational studies (9), retrospective studies using patient data (7), cross-sectional studies (4), systematic reviews (3), cohort studies (3), a randomized trial (1), and a longitudinal analysis (1). The data were also obtained from educational texts (7), review articles (2) and expert disputations (2).

\section{Data analysis}

A total of 65 publications were found, thirty-nine of which fulfilled the inclusion criteria; this group of studies was included in the thematic analysis. A total 
of three topics were defined based upon the obtained results, depending upon the focus of the studies on: (a) accuracy of nursing diagnoses (including characteristic features and related factors), (b) frequency of nursing diagnoses, and (c) factors influencing the use of clinical diagnoses in clinical practice. The results of assorted studies based upon the thematic focus were organized in three tables (see Tables 1-3).

\section{Results}

\section{The most frequent mistakes in the diagnostics}

In their study aimed at analyzing the expressions or terms used in Iceland to describe patient problems, Thoroddsen and Thorsteinsson (2002) found that nursing diagnoses were defined according to the NANDA I terminology in only sixty percent. Doenges and Moorhouse (2003) characterized the eight most frequently occurring mistakes in formulation of nursing diagnoses (Table 1). The results of a study performed in Sweden (Florin et al., 2005) did not reveal any issues related to formulation of the nursing problem; the nursing diagnosis was stated precisely and exactly in most of the diagnoses. However, serious deficiencies were found in the concept of etiology. A method similar to the one in Sweden was also used in Slovakia by Žiaková, Holmanová and Č́p (2007), who in their study identified the occurrence of the most frequent problems related to formulation of the diagnostic summary. Most of the observed mistakes were included in the category related to the relevance of documented diagnostic signs, and in the category pertaining to the structure of the diagnosis (Table 1). Müller-Staub et al. (2006) published a systematic review of fourteen literary sources dealing with the effects of nursing diagnoses upon the quality of patient assessment and frequency of the documented nursing diagnoses. All these fourteen peer-reviewed studies point out deficiencies in the accuracy of the determined diagnoses. Some studies also refer to insufficient knowledge of nurses in the area of etiology. Similar conclusions were also described one year later (Müller-Staub et al., 2007) in a study aimed at assessing the impact of an educational program on correct formulation of nursing diagnoses, including characteristic features and related factors, on suitable selection of nursing interventions specified for the identified etiology, and on adequately proposed measurable and achievable nursing outcomes describing changes in the patient condition (Table 1).

\section{The frequency of nursing diagnoses}

The authors Thoroddsen and Thorsteinsson (2002) analyzed nursing records of patients hospitalized at intensive care units, and found out that the number of diagnoses per one patient was between 0 and 10; in 65 percent of patients, three or less diagnoses were identified. The number of diagnoses correlated with the length of hospitalization but not with the increasing age of the patients. The mean number of nursing diagnoses per one patient was 3.28. Diagnoses pertaining to dysfunctions of body functions dominated; the frequency of diagnosed psychosocial problems was significantly lower (Table 2). Another study was performed in Japan (Ogasawara et al., 2005); its aim was to assess the use of nursing diagnoses and interventions in female patients in terminal stage of breast cancer. A total of 539 diagnostic conclusions were identified, a total of 96 diagnoses were used in relation to this type of diagnosis, 47 percent of the diagnoses were used from NANDA I taxonomy. Diagnoses from the psychosocial area were used only sparsely, the authors also revealed an absence of diagnoses aimed at the problems of care provided for dying patients and their families (Table 2). A systematic review of fourteen literary sources (Müller-Staub et al., 2006, p. 519) identified a high frequency of nursing diagnoses. Sixty percent of the records included between 1 and 10 nursing diagnoses. From the summary, it becomes apparent that the frequency of using nursing diagnoses varies, depending on the geographical location and the healthcare establishment (Table 2). Another study aimed at the frequency of nursing diagnoses was performed in Slovakia by Pavelová (2005). The author performed and analysis of a relatively small sample, when compared to other studies performed abroad, of thirty records of patients hospitalized at an intensive care unit and identified the most frequent diagnoses (Table 2). Authors from Brazil, Lucena and Barros (2006), performed a survey, the aim of which was to identify nursing diagnoses and the most frequently listed related or risk factors. The data was obtained on the basis of a retrospective analysis of nursing records of patients hospitalized at intensive care units. A total of sixteen most frequently occurring nursing diagnoses were defined, twelve acute and four potential. Yet again, diagnoses from the psychosocial and spiritual area were absent (Table 2). According to the authors, on the one hand, such observation could be expected, due to the fact that the condition of patients hospitalized at intensive care units is serious, and the imminent threat to life defines biological needs as a priority. However, on the other hand, it is a well-known fact that many patients at intensive care units encounter problems related to communication, social isolation and spiritual suffering. 
Table 1 Overview of publications dealing with identifying mistakes in diagnostics

\begin{tabular}{|c|c|}
\hline Authors, year & Identified mistakes in diagnostics \\
\hline $\begin{array}{l}\text { Doenges, } \\
\text { Moorhouse, } 2003\end{array}$ & $\begin{array}{l}\text { Use of medical diagnoses, complications of the disease or side effects of the treatment in formulation of the problem. } \\
\text { Use of irreversible situations, which cannot be changed with formulation of related factors. } \\
\text { Naming of individual symptoms of a disease with nursing diagnoses. } \\
\text { Use of nursing interventions in formulation of a nursing problem. } \\
\text { Lack of specificity, which does not determine the focus of nursing interventions. } \\
\text { One nursing diagnosis includes two or more nursing problems. } \\
\text { General determination of related factors and characteristic features, which do not specify nursing interventions and cannot be } \\
\text { influenced with nursing interventions. } \\
\text { Nursing diagnoses are defined on the basis of irrelevant or non-valid data. } \\
\text { Diagnoses are automatically predefined within a medical diagnosis in every patient. }\end{array}$ \\
\hline $\begin{array}{l}\text { Florin, Ehrenberg, } \\
\text { Ehnfors, } 2005\end{array}$ & $\begin{array}{l}\text { Etiology not determined. } \\
\text { The identified etiology was insufficiently precise and did not specify the focus of nursing interventions. } \\
\text { The identified etiology could not be influenced with nursing interventions. }\end{array}$ \\
\hline $\begin{array}{l}\text { Müller-Staub et al., } \\
2006\end{array}$ & $\begin{array}{l}\text { Imperfections in the accuracy of determined diagnoses. } \\
\text { Imperfections in the systematic evaluation of characteristic features. } \\
\text { Poor correlation between related factors and nursing diagnoses. } \\
\text { Related factors were not described, or were only partially documented. }\end{array}$ \\
\hline $\begin{array}{l}\text { Müller-Staub et al., } \\
2007\end{array}$ & $\begin{array}{l}\text { Incorrect formulation of nursing diagnostic terms. } \\
\text { Insufficient identification of related factors and characteristic features. } \\
\text { Improperly determined objectives of the nursing care. }\end{array}$ \\
\hline $\begin{array}{l}\text { Thoroddsen, } \\
\text { Thorsteinsson, } \\
2002\end{array}$ & $\begin{array}{l}\text { Nursing interventions, medical diagnoses or risk of complications related to a medical procedure or treatment were listed as } \\
\text { nursing problems. } \\
\text { Diagnostic conclusions did not correspond with the formulation of nursing diagnoses in NANDA I. } \\
\text { One nursing diagnosis included two or more nursing problems. }\end{array}$ \\
\hline $\begin{array}{l}\text { Žiaková, } \\
\text { Holmanová, Čáp, } \\
2007\end{array}$ & $\begin{array}{l}\text { Automatic allocation of diagnoses to patients in perioperative care. } \\
\text { Diagnostic terms were not supported with relevant data, using evaluation scales. } \\
\text { The identified etiology was not sufficiently specific and did not specify the focus of nursing interventions. } \\
\text { The identified etiology could not be influenced with nursing interventions. }\end{array}$ \\
\hline
\end{tabular}

In the Czech Republic, Marečková and Tománková (2007) identified the most frequent nursing diagnoses in patients with an impairment of consciousness. The authors proposed a group of 32 nursing diagnoses; a frequency of at least 10 percent was observed in 29 nursing diagnoses from the proposed file. In case of 15 diagnoses, the frequency reached 100 percent (Table 2). Marečková and Tomanová concluded their study with a recommendation to create specially designed groups of probands for the purpose of research analysis related to nursing diagnostics, according to the types of illness or time factor, that is, inclusion of probands in individual stages of continuous care. In 2010, Thoroddsen, Ehnfors and Ehrenberg performed a study examining the use of standardized nursing terminology in nursing records in four selected specialties (surgery, internal medicine, geriatrics and psychiatry). They were able to allocate a total of 1261 nursing conclusions, when a total of 63 diagnoses were used in relation of the type of diagnosis within all four specialties. The performed study revealed an extensive use and variability in the area of nursing diagnoses in these four nursing specialties. The most frequently observed nursing diagnoses across all specialties represent the basic human needs of the patients (Table 2). From the group of nine nursing diagnoses which were common for all clinical specialties, eight represented the basic needs of patients, including sleep, nutrition, elimination, self-care, and problems with the skin, emotions and reasoning. The frequency of nursing diagnoses in patients in home care in the Czech Republic was assessed within a project which attempted to bridge the gap between the current theoretical knowledge and the outcomes of research and the nursing practice in the area of nursing diagnostics, planning and documentation of nursing care. One of the four aims of the project was to create a basic file of NANDA I nursing diagnoses suitable for specific groups of clients in home care (Table 2). The project confirmed a good usability of the systematic international terminology NANDA I and NIC in nursing practice. The results of the study also showed that the use of universal nursing terminology, especially NIC, could be beneficial for description and records of the work of nurses (Jarošová, 2012, p. 94). 
Table 2 Overview of publications dealing with the frequency of nursing diagnoses

\begin{tabular}{|c|c|c|}
\hline Authors, year & $\begin{array}{l}\text { Observed } \\
\text { workplaces/patients }\end{array}$ & Nursing diagnoses \\
\hline Jarošová et al., 2012 & Homecare & $\begin{array}{l}\text { Risk of falls (00155), Impaired mobility (00085), Risk of infection (00004), Chronic pain } \\
\text { (00133), Risk for deficient fluid volume (00028), Dressing or grooming self-care deficit } \\
\text { (00109), Bathing or hygiene self-care deficit (00108), Disturbed thought processes } \\
(00130) \text {, Risk of disrupted skin integrity (00047). }\end{array}$ \\
\hline Lucena, Barros, 2006 & Intensive care unit & $\begin{array}{l}\text { Bathing or hygiene self-care deficit, Risk of infection, Impaired mobility, Ineffective } \\
\text { breathing, Impaired spontaneous ventilation, Risk of disrupted skin integrity. }\end{array}$ \\
\hline $\begin{array}{l}\text { Marečková, Tománková, } \\
2007\end{array}$ & $\begin{array}{l}\text { Patients with impaired } \\
\text { consciousness }\end{array}$ & $\begin{array}{l}\text { Risk of falls (00155), Impaired mobility (00085), Risk of infection (00004), Chronic pain } \\
\text { (00133), Risk for deficient fluid volume (00028), Dressing or grooming self-care deficit } \\
\text { (00109), Bathing or hygiene self-care deficit (00108), Disturbed thought processes } \\
(00130) \text {, Risk of disrupted skin integrity (00047). }\end{array}$ \\
\hline \multirow[t]{2}{*}{ Müller-Staub et al., 2006} & Patients with leukemia & $\begin{array}{l}\text { Lack of sleep, Disrupted skin integrity, Pain, Imbalanced nutrition, Nausea, Self-care } \\
\text { deficit. }\end{array}$ \\
\hline & $\begin{array}{l}\text { Establishments of acute } \\
\text { psychiatric care }\end{array}$ & Ineffective coping, Disrupted thought processes, Self-care deficit. \\
\hline Ogasawara et al., 2005 & $\begin{array}{l}\text { Patients in terminal stage } \\
\text { of breast cancer }\end{array}$ & $\begin{array}{l}\text { Chronic pain, Risk of infection, Risk of injury, Intolerance of activity, Changed nutrition, } \\
\text { Anxiety. }\end{array}$ \\
\hline Pavelová, 2005 & Intensive care units & Acute pain, Fear, Risk of infection. \\
\hline $\begin{array}{l}\text { Thoroddsen, Thorsteinsson, } \\
2002\end{array}$ & Intensive care units & Self-care deficit, Impaired mobility, Disrupted skin and tissue integrity, Hyperthermia. \\
\hline \multirow[t]{4}{*}{$\begin{array}{l}\text { Thoroddsen, Ehnfors, } \\
\text { Ehrenberg, } 2010\end{array}$} & Surgery & $\begin{array}{l}\text { Risk of surgical complications, Non-effective patency of breathing passageways, Impaired } \\
\text { gastrointestinal function, Preparation for discharge, Self-care deficit, Pain, Impaired } \\
\text { mobility, Constipation, Disrupted sleep, Disrupted thought processes, Insufficient } \\
\text { nutrition, Disrupted skin integrity, Risk of disrupted skin integrity, Disrupted tissue } \\
\text { integrity, Risk of disrupted tissue integrity. }\end{array}$ \\
\hline & Internal medicine & $\begin{array}{l}\text { Non-effective breathing, Insufficient nutrition and Insufficient tissue perfusion. } \\
\text { Preparation for discharge, Self-care deficit, Pain, Impaired mobility, Constipation, } \\
\text { Disrupted sleep, Disrupted thought processes, Insufficient nutrition, Disrupted skin } \\
\text { integrity, Risk of disrupted skin integrity, Disrupted tissue integrity, Risk of disrupted } \\
\text { tissue integrity. }\end{array}$ \\
\hline & Geriatrics & $\begin{array}{l}\text { Chronic confusion, Constipation, Risk of falls, Preparation for discharge, Self-care deficit, } \\
\text { Pain, Impaired mobility, Disrupted sleep, Disturbed thought processes, Insufficient } \\
\text { nutrition, Disrupted skin integrity. Risk of disrupted skin integrity, Disrupted tissue } \\
\text { integrity, Risk of disrupted tissue integrity. }\end{array}$ \\
\hline & Psychiatry & $\begin{array}{l}\text { Disrupted sleep, Impaired social interaction, Preparation for discharge, Self-care deficit, } \\
\text { Constipation, Disrupted sleep, Disrupted thought processes, Insufficient nutrition, } \\
\text { Disrupted skin integrity. Risk of disrupted skin integrity, Disrupted tissue integrity, Risk } \\
\text { of disrupted tissue integrity. }\end{array}$ \\
\hline
\end{tabular}

\section{Factors influencing the use of nursing diagnoses in clinical practice}

The analysis of literary sources dealing with nursing diagnostics revealed four basic factors which significantly influence the quality of nursing diagnostics: the nurse, education in the area of diagnostics, condition of the patient, institutional support and organization factors.

\section{The nurse}

The authors Carnevali and Thomas (1993) and Gordon (1994) consider the nurse as a significant factor influencing the accuracy of diagnostics. Furthermore, Brannon and Carson (2003) consider also education in clinical diagnostics, diagnostic experience and skills of the nurse in intellectual, interpersonal and technical areas to be influencing factors in the process of clinical decision-making. Also other authors put emphasis on the necessity of interpersonal communication skills of nurses (Lunney, 2008; Munhall, 1993; Tanner, 2006;
McCabe, 2004). According to Lunney (2010), it is important for the nurse, in order to be a good diagnostician, to master three types of competences, namely intellectual, interpersonal and technical competences. An important aspect encompassing intellectual competence is the ability of critical and sometimes also clinical reasoning, which is necessary in order to obtain exact patient data and a suitable choice of interventions. Paans et al. (2011) confirmed that the accuracy of nursing diagnoses positively influenced the ability of nurses to use critical reasoning and the degree of experiences and knowledge concerning diagnostics. Also Žiaková et al. (2013) stated that the attitude to substantiating a nursing diagnosis and nurses' critical reasoning may influence the way in which they document their diagnostic conclusions (Table 3 ).

\section{Education in the area of diagnostics}

The beneficial impact of educational sessions aimed at the nursing process has been confirmed by a study 
monitoring the effect of an educational program for registered nurses, which was aimed at improving knowledge in the nursing process (Florin et al., 2005). The results of analysis of fourteen studies performed by Müller-Staub et al. (2006) show that the use of educational programs aimed at nursing diagnostics significantly influences the quality of formulation of nursing diagnoses and management of nursing documentation. Another study was performed in 2007, with the aim to assess the impact of an educational program upon the correctness of nursing diagnoses, including characteristic features and related factors. Following the implementation of the planned educational program, the authors observed a significant improvement in the quality of the documented nursing diagnoses, interventions and outcomes (Müller-Staub et al., 2007). The need for educational programs in the area of nursing diagnostics has been also confirmed by Cruz et al. (2009). Carpenito-Moyet (2010) pointed to the fact that although the curriculum of nursing education includes education regarding the nursing process and nursing diagnoses, a transfer of these basic elements into practice is missing. Pospíśilová et al. (2012) recommended that greater attention is paid to the process of teaching the nursing diagnostics, including the NIC and NOC classification systems, at all levels of the educational process. With this proclamation, the authors also emphasized the fact, that postgraduate specialization education in the Czech Republic is aimed more at improving knowledge in the individual specialized areas, rather than improving knowledge in the area of nursing as a whole. Dolák, Scholz and Tóthová (2012) in their observations claim that nurses do not have a positive attitude to the use of standardized nursing classification systems; the greatest tendency to neglect the use of the system of nursing diagnoses may be observed in nurses with the longest experience in practice, and nurses with secondary nursing education. The authors see the starting point in order to ensure a systematic use of nursing diagnoses mainly in implementation of educational programs aimed at the issues of nursing diagnostics in individual healthcare establishments. In relation to education, Žiaková et al. (2013) referred to the lack of high-quality expert publications available in the national languages; the authors also stress the fact that nursing, as a scientific discipline, experiences a great development of knowledge, which, however, is only minimally applied in practice (Table 3 ).

\section{Condition of the patient}

Another fact influencing the nursing diagnostics is the severity of the patient's condition. Paans et al.
(2011, p. 2391), authors of a systematic review, identified three factors: cultural diversity in expressing the patient's needs, seriousness of the medical diagnose in specialized areas, and the means of expressing serious diagnoses. Also according to Ogasawara et al. (2005), the absence of nursing diagnoses associated with dying and death is related to socio-cultural influences, which affect the attitudes and behavior of nurses towards terminally ill patients. Many patients and their families may have difficulties expressing their feelings towards healthcare professionals. The unwillingness of patients to speak about certain problems has been identified as a barrier, which influences the use of the nursing diagnostics; this fact represents a finding of a study aimed at identifying the stimuli and barriers in the use of nursing diagnoses (Žiaková et al., 2013).

\section{Institutional support and organization factors}

A very commonly mentioned factor influencing the accuracy of nursing diagnostics is the administrative load on nurses. Hedberg and Larsson (2004), Paganin et al. (2008), Paans et al. (2011) or Macková and Zeleníková (2012) refer to the observation that nurses are required, apart from other activities, to perform also technical and administrative duties, and thus have less time for the nursing process. Similar conclusions were drawn also in other studies, determining how the nurses spend their working time, which showed that approximately half of the nurses' time is consumed by performing indirect interventions (work with patient records, etc.), and only one third of the time is spent on direct interventions (Bulechek et al., 2006; Hendrich et al., 2008; Munyisia, 2011) (Table 3).

Also Cheevakasemsook et al. (2006) dealt with obstacles related to nursing documentation. In their study, the authors determined three areas related to the complexities of nursing documentation; these were the disruption, inappropriate charting and incompleteness. The authors recommend to perform a revision and modification of the nursing documentation, based upon the requirements arising from practice, and also to educate nurses in this area. Many authors also refer to the fact that the method, which may significantly relieve the administrative load placed on nurses, is the implementation of electronic medical records. Another advantage of the electronic patient record is the possibility to ensure exact and measureable information and statistical data for evidence of the nursing care, planning of costs related to nursing care and research data (Jerant et al., 2001; Lavin et al., 2004; Levin, McEwan, 2001; Brokel, Heath, 2010, Jarošová, 2012) (Table $3)$. 
Table 3 Overview of publications dealing with factors influencing the use of nursing diagnoses

\begin{tabular}{|c|c|}
\hline Authors, year & Factor \\
\hline Bostick et al., 2006 & The number of patients per one nurse. \\
\hline Brannon, Carson, 2003 & $\begin{array}{l}\text { Diagnostic experience of nurses, abilities } \\
\text { and skills of nurses in intellectual, } \\
\text { interpersonal and technical areas. }\end{array}$ \\
\hline Brokel, Heath, 2010 & $\begin{array}{l}\text { Implementation of electronic medical } \\
\text { records. }\end{array}$ \\
\hline Bulechek, Butcher, Dochterman 2008 & Administrative load on nurses. \\
\hline Carnevali, Thomas, 1993 & Nurse as a diagnostician. \\
\hline Carpenito-Moyet, 2010 & $\begin{array}{l}\text { The use of educational programs aimed at } \\
\text { nursing diagnostics for registered nurses. }\end{array}$ \\
\hline $\begin{array}{l}\text { Cruz, Pimenta, Lunney, } 2009 \\
\text { Červinková, Marečková, } 2007\end{array}$ & $\begin{array}{l}\text { nursing diagnostics for registered nurses. } \\
\text { Legislation determining the minimal staffing } \\
\text { and competences within a nursing team. }\end{array}$ \\
\hline Dolák, Scholz, Tóthová, 2012 & $\begin{array}{l}\text { The use of educational programs aimed at } \\
\text { nursing diagnostics for registered nurses. }\end{array}$ \\
\hline Florin, Ehrenberg, Ehnfors, 2005 & $\begin{array}{l}\text { The use of educational programs aimed at } \\
\text { nursing diagnostics for registered nurses. }\end{array}$ \\
\hline Gordon, 1994 & Nurse as a diagnostician. \\
\hline Hedberg, Larsson, 2004 & Administrative load on nurses. \\
\hline Hendrich, 2008 & Administrative load on nurses. \\
\hline Cheevakasemsook, 2006 & $\begin{array}{l}\text { Administrative load on nurses, unsuitable } \\
\text { and complex structure of the nursing } \\
\text { documentation. }\end{array}$ \\
\hline Jarošová, 2012 & $\begin{array}{l}\text { Implementation of electronic medical } \\
\text { records, legislation determining the minimal } \\
\text { staffing and competences within a nursing } \\
\text { team. }\end{array}$ \\
\hline Jerant, Azari, Nesbitt, 2001 & \multirow{3}{*}{$\begin{array}{l}\text { Implementation of electronic medical } \\
\text { records. }\end{array}$} \\
\hline Lavin et al., 2004 & \\
\hline Levin, McEwan, 2001 & \\
\hline Lunney, 2008 & $\begin{array}{l}\text { Interpersonal and communication skills of } \\
\text { nurses, the number of patients per one nurse. } \\
\text { Organization of nursing care in individual } \\
\text { healthcare establishments. }\end{array}$ \\
\hline Lunney, 2010 & $\begin{array}{l}\text { The ability of critical reasoning, intellectual, } \\
\text { interpersonal and technical competences of } \\
\text { nurses. }\end{array}$ \\
\hline Macková, Zeleníková, 2012 & $\begin{array}{l}\text { Administrative load on nurses, the number of } \\
\text { patients per one nurse. }\end{array}$ \\
\hline Munhall, 1993 & $\begin{array}{l}\text { Interpersonal communication skills of } \\
\text { nurses. }\end{array}$ \\
\hline McCabe, 2004 & \multirow{3}{*}{$\begin{array}{l}\text { The use of educational programs aimed at } \\
\text { nursing diagnostics for registered nurses. }\end{array}$} \\
\hline Müller-Staub et al., 2006 & \\
\hline Müller-Staub et al., 2007 & \\
\hline Munyisia, Yu, Haley, 2011 & $\begin{array}{l}\text { Administrative load on nurses, } \\
\text { implementation of electronic medical } \\
\text { records. }\end{array}$ \\
\hline Ogasawara et al., 2005 & $\begin{array}{l}\text { Social-cultural influences affecting the } \\
\text { attitudes and behavior of nurses towards } \\
\text { terminally ill patients. }\end{array}$ \\
\hline Paans et al., 2011 & $\begin{array}{l}\text { Diagnostic experience and the ability of } \\
\text { critical reasoning of nurses. Cultural } \\
\text { differences in patient diction. Seriousness of } \\
\text { medical diagnoses in specialized areas. }\end{array}$ \\
\hline Paganin et al., 2008 & $\begin{array}{l}\text { Administrative load on nurses, the number of } \\
\text { patients per nurse. }\end{array}$ \\
\hline Pospíšilová, Kyasová, Juřeníková, 2012 & $\begin{array}{l}\text { Lack of teaching of the nursing diagnostics } \\
\text { in postgraduate specialization education. } \\
\text { Missing legislation in the Czech Republic in } \\
\text { the area of classification of the nursing } \\
\text { diagnostics. }\end{array}$ \\
\hline Tanner, 2006 & $\begin{array}{l}\text { Interpersonal and communication skills of } \\
\text { nurses. }\end{array}$ \\
\hline Žiaková et al., 2013 & $\begin{array}{l}\text { Competences and organization of the nursing } \\
\text { care, education and attitude of nurses } \\
\text { towards diagnostics. }\end{array}$ \\
\hline
\end{tabular}


The number of patients per one nurse is considered a factor which most significantly influences the use and accuracy of nursing diagnoses in practice (Bostick et al., 2006; Lunney, 2008; Paganin et al., 2008; Paans et al., 2011; Macková, Zeleníková, 2012). Červinková and Marečková (2007) and later on also Jarošová (2012) reported on the vaguely defined rules for competences of nursing professionals and the need to specifically determine the roles of individual members of nursing teams on the international level. Also Pospíšilová, Kyasová and Juřeníková (2012) refer to the missing legislative framework as a supporting system in the implementation of a unified language of nursing within the Czech Republic. A similar issue regarding staffing is being discussed in Slovakia, where the healthcare establishments comply only with the minimal requirements, which, in some cases, do not correspond with the actual needs of providing care (Žiaková et al., 2013) (Table $3)$.

\section{Discussion}

From the listed studies it becomes apparent that there exist repeated deficiencies in the formulation of the diagnostic conclusion, as well as in identification of diagnostic elements; the nursing diagnoses are very often determined on the basis of irrelevant or invalid data. As far as the frequency of nursing diagnoses is concerned, diagnoses pertaining to dysfunctional body functions prevail, whereas diagnoses from the psychosocial area are mentioned only sparsely. The low incidence of mental, social and spiritual diagnoses may be explained by the fact that nurses are traditionally used to diagnosing identical nursing problems within individual medical diagnoses. Nurses most probably perceive their limited competences in dealing with mental, social or spiritual problems of patients. This fact most probably originates in the nursing care being primarily aimed at physical and executive elements, due to a well-established biomedical module. Many patients may also have emotional problems, or they may not be able to express their feelings towards the healthcare professionals. Another significant factor influencing the accuracy of the nursing diagnostics are the communication and interpersonal skills of nurses, the ability of critical reasoning and the degree of experience and knowledge regarding diagnostics. Significant role is also played by the nursing education in the area of the nursing process, at all levels of the educational process. Many authors point out another fact which negatively influences the accuracy of nursing diagnoses, that is, the administrative load, including unsuitable structure of the nursing documentation. According to some authors, implementation of electronic medical records may significantly relieve the administrative load placed upon nurses. According to conclusions of the analyzed studies, the factor which most significantly influences the use and accuracy of nursing diagnoses in practice is the number of patients per one nurse. The minimum staffing requirements in the Czech Republic are defined in the Decree No. 99/2012 Coll., which states that the nursing care at inpatient standard, intensive, followup and long-term care facilities is provided by general nurses or medical assistants (Czech, 2012). Due to personal costs and the current economic situation, healthcare establishments prefer to employ medical assistants rather than general nurses. Nevertheless, the Decree No. 55/2011 regarding the activities of healthcare professionals and other specialized workers states that medical assistants are not allowed to work independently, but only under supervision; however, the required extent and scope of the supervision is not defined. Managers of some healthcare establishments deal with this issue by establishing a telephone reach of a registered general nurse who is entitled to work without supervision.

\section{Conclusion}

Effective and efficient nursing care is a precondition for providing safe care. The analyzed works show that in order to achieve the maximum efficacy, a holistic approach is required, that is, mutual interconnection among nurses with appropriate education and experiences in the area of nursing diagnoses, institutional support, including adequate staffing, hospital working environment, and the technology of nursing documentation.

\section{Ethical aspects and conflict of interest}

The authors are not aware of any conflict of interest.

\section{References}

Brokel J, Heath, C. Hodnota ošetřovatelských diagnóz v elektronických záznamech. In: NANDA International. Ošetřovatelské diagnózy: definice a klasifikace 2009 - 2011. Praha: Grada; 2010. p. 26-29. (in Czech)

Bostick JE, Rantz MJ, Flesner MK, Riggs CJ. Systematic review of studies of staffing and quality in nursing homes. Journal of the American Medical Directors Association. 2006;7(6): 366-376.

Bulechek GM, Butcher HK, Dochterman MJ. Nursing Interventions Classifications (NIC). 5th ed. St. Louis: Mosby; 2008.

Brannon LA, Carson KL, The representative heuristic: influence on nurses' decision making. Applied Nursing Research. 2003;16(3): 201-204. 
Carnevali DL, Thomas MD. Diagnostic Reasoning and Treatment Decision Making in Nursing. Philadelphia: Lippincott; 1993.

Carpenito-Moyet LJ. Invited paper: Teaching nursing diagnosis to increase utilization after graduation. International Journal of Nursing Terminologies and Classifications. 2010;21(3):124-133.

Cruz DM, Pimenta CM, Lunney, M. Improving critical thinking and clinical reasoning with a continuing education course. The Journal of Continuing Education in Nursing. 2009;40 (3):121-127.

Czech. Ministerstvo zdravotnictví. Vyhláška č. 55 ze dne 1. března 2011 o činnostech zdravotnických pracovníků a jiných odborných pracovníků. In: Sbirka zákonů České republiky. 2011, částka 20, p. 482-544. (in Czech)

Czech. Ministerstvo zdravotnictví. Vyhláška č. 98 ze dne 22. března 2012 o zdravotnické dokumentaci. In: Sbirka zákonů České republiky. 2012, částka 39, p. 1666-1685. (in Czech) Czech. Ministerstvo zdravotnictví. Vyhláška č. 99 ze dne 22. března 2012 o požadavcích na minimální personální zabezpečení zdravotních služeb. In: Sbírka zákonů České republiky. 2012, částka 39, p. 1686-1730. (in Czech)

Červinková L, Marečková J. Zkušenosti s výukou ošetřovatelské diagnostiky na střední zdravotnické škole. (In: Bužgová R, Jarošová D. Ošetrovatelská diagnostika a praxe založená na dỉkazech. Ostrava; 2007. p. 40-44. (in Czech)

Doenges ME, Moorhouse MF. Application of Nursing Process and Nursing Diagnosis. An Interactive Text for Diagnostic Reasoning. 4th ed. F. A. Davis Company: Philadelphia; 2003.

Dolák F, Scholz P, Tóthová V. Postoj sester k ošetřovatelským klasifikačním systémům. Kontakt. 2012;14(4):434-443. (in Czech)

Gordon M. Nursing Diagnosis: Process and Application. 3th ed. St. Louis: Mosby; 1994.

Florin J, Ehrenberg A, Ehnfors M. Quality of nursing diagnoses: evaluation of an educational intervention. International Journal of Nursing Terminologies and Classifications. 2005;16(2): 33-43.

Hedberg B, Larsson US. Environmental elements affecting the decision-making process in nursing practice. Journal of Clinical Nursing. 2004;13(3):316-324.

Hendrich A, Chow M, Skierczynski BA, Lu Z. A 36-hospital time and motion study: how do medical-surgical nurses spend their time? The Permanente Journal. 2008;12(3):25-34.

Cheevakasemsook A, Chapman Y, Francis K, Davies C. The study of nursing documentation complexities. International Journal of Nursing Practice. 2006;12(6): 366-374.

Jarošová D. Ověřování souboru ošetřovatelských diagnóz a intervencí pro domácí péči. In: Jarošová D, editor. Využitelnost ošetřovatelských klasifikací NANDA International a NIC v domácí péći. Ostrava: OU v Ostravě, LF; 2012. p. 86-99. (in Czech)

Jerant AF, Azari R, Nesbitt TS. Reducing the cost of frequent hospital admissions for congestive heart failure: a randomized trial of a home telecare intervention. Medical Care. 2001;39(11):1234-1245.

Lavin MA, Avant K, Craft-Rosenberg M, Herdman TH, Gebbie K, Michel J, de Barros A, Apalategui MU. Context for the study of the economic influence of nursing diagnoses on patient outcomes. International Journal of Nursing Terminologies and Classifications. 2004;15(2): 39-47.
Levin HM, McEwan PJ. Cost-Effectiveness Analysis: Methods and Applications. 2nd ed. Thousand Oaks: Sage Publications; 2001.

Lucena AF, Barros ALBL. Nursing diagnoses in a Brazilian intensive care unit. International Journal of Nursing Knowledge. 2006;17(3):139-146.

Lunney M. Critical need to address accuracy of nurses' diagnoses. The Online Journal of Issues in Nursing. 2008;13(1)

Lunney M. Hodnocení, klinické posouzení a ošetřovatelské diagnózy: jak určit přesnou diagnózu. In: NANDA International. Ošetrovatelské diagnózy: definice a klasifikace 2009 - 2011. Praha: Grada; 2010. p. 3-15. (in Czech)

Macková H, Zeleníková R. Faktory ovlivňující používání ošetřovatelských diagnóz v praxi. Ořetřovatelství a porodni asistence. 2012;3(2): 390-397. (in Czech)

Marečková J, Stefanová P, Mazalová L, Bocková S. Přehled informací k mezinárodním terminologickým systémům v ošetřovatelství. In: Jarošová $\mathrm{D}$, editor. Využitelnost ošetrovatelských klasifikací NANDA International a NIC $v$ domáci péči. Ostrava: OU v Ostravě, LF; 2012. p. 7-24. (in Czech)

Marečková J, Tománková I. Diagnostické prvky NANDA International $\mathrm{u}$ bezvědomých pacientů. In: Bužgová $\mathrm{R}$, Jarošová $\mathrm{D}$, editors. Ošetřovatelská diagnostika a praxe založená na dưkazech. Ostrava; 2007. p. 58-64. (in Czech)

McCabe C. Nurse-patient communication: an exploration of patients' experiences. Journal of Clinical Nursing. 2004;13(1): 41-49.

Munhall PL. "Unknowing": toward another pattern of knowing in nursing. Nursing Outlook. 1993;41(3):125-128.

Munyisia EN, Yu P, Haley D. Does the introduction of an electronic nursing documentation system in nursing home reduce time on documentation for nursing staff? International Journal of Medical Informatics. 2011;80(11):782-792.

Müller-Staub M, Lavin MA, Needham I, Van Achterberg T. Nursing diagnoses, interventions and outcomes - application and impact on nursing practice: systematic review. Journal of Advanced Nursing. 2006;56(5):514-531.

Müller-Staub M, Needham I, Odenbreit M, Lavin MA, Van Achterberg T. Improved quality of nursing documentation: results of a nursing diagnoses, interventions, and outcomes implementation study. International Journal of Nursing Terminologies and Classifications. 2007;18(1):5-17.

Ogasawara, C, Hasegawa T, Kume Y, Takahashi I, Katayama Y, Furuhashi Y, Andoh M, Yamamoto Y, Okazaki S, Tanabe M. Nursing diagnoses and interventions of Japanese patients with end-stage breast cancer admitted for different care purposes. International Journal of Nursing Terminologies and Classifications. 2005;16(3-4):54-64.

Paans W, Nieweg RMB, Van der Schans CP, Sermeus W. What factors influence the prevalence and accuracy of nursing diagnoses documentation in clinical practice? A systematic literature review. Journal of Clinical Nursing. 2011;20(17-18):2386-2403.

Paganin A, Moraes MA, Pokorski S, Rabelo ER. Factors that inhibit the use of nursing language. International Journal of Nursing Terminologies and Classifications. 2008;19(4):150157.

Pavelová L, Nádaská I, Mesárošová J, Pet'ková J. Sesterská diagnostika $\mathrm{v}$ ošetrovatel'skom procese $\mathrm{u}$ pacientov v kritickom stave. In: Ošetrovatel'stvo 21. storočia v procese zmien. Univerzita Konštantína Filozofa v Nitre. Fakulta 
sociálnych vied a zdravotníctva, Katedra ošetrovatel'stva; 2005. p. 343-346. (in Slovak)

Pospíšilová A, Kyasová M, Juřeníková, P. Knowledge of NANDA International, NIC and NOC concepts in terms of education of general nurses. Kontakt. 2012;14(4): 421-433.

Tanner CA. Thinking like a nurse: a research-based model of clinical judgment in nursing. Journal of Nursing Education. 2006;45(6):204-211.

Thoroddsen A, Thorsteinsson HS. Nursing diagnosis taxonomy across the Atlantic Ocean: congruence between nurses' charting and the NANDA taxonomy. Journal of Advanced Nursing. 2002;37(4):372-381.

Thoroddsen A, Ehnfors M, Ehrenberg A. Nursing specialty knowledge as expressed by standardized nursing languages.
International Journal of Nursing Terminologies and Classification. 2010;21(2):69-79.

Žiaková K, Holmanová E, Č́p J. Reflexia aplikácie ošetrovatel'ských diagnóz vo vzdelávaní. In: Bužgová R, Jarošová $\mathrm{D}$, editors. Ošetřovatelská diagnostika a praxe založená na důkazech. Ostrava; 2007. p. 100-105. (in Slovak) Žiaková K, Holmanová E, Čáp J. Problematika odbornej terminologie v ošetrovatel'stve. In: Bužgová R, Sikorová L, editors. Ošetřovatelská diagnostika a praxe založená na dikkazech II. Ostrava; 2008. p. 83-86.

Žiaková K, Gurková E, Šerfelová R, Čáp J. Stimuly a bariéry vo využívaní ošetrovatel'ských diagnóz. Ošetřovatelství a porodni asistence. 2013;4(3):601-608. (in Slovak) 